8 - ORIGINAL ARTICLES

\title{
Comparative evaluation of oncologic outcomes in colon cancer ${ }^{1}$
}

\author{
Mário Vinícius Angelete Alvarez Bernardes', Marley Ribeiro Feitosa ${ }^{\mathrm{II}}$, Fernanda Maris Peria ${ }^{\mathrm{III}}$, Daniela Pretti da Cunha \\ Tirapelli $^{\mathrm{IV}}$, José Joaquim Ribeiro da Rochav ${ }^{\mathrm{V}}$ Omar Feres ${ }^{\mathrm{VI}}$
}

DOI: http://dx.doi.org/10.1590/S0102-86502016001300008

${ }^{\mathrm{I}}$ Fellow PhD degree, Department of Surgery and Anatomy, Ribeirão Preto Medical School, University of São Paulo. Conception and design of the study, acquisition of data, manuscript writing, manuscript review.

IIMD, Division of Coloproctology, Department of Surgery and Anatomy, Ribeirão Preto Medical School, University of São Paulo. Conception and design of the study, acquisition of data, manuscript writing, manuscript review.

IIIPhD, Head of Division of Clinical Oncology, Ribeirão Preto Medical School, University of São Paulo. Manuscript review.

${ }^{\text {IV }}$ hD, Department of Surgery and Anatomy, Ribeirão Preto Medical School, University of São Paulo. Manuscript review.

${ }^{\mathrm{V}} \mathrm{PhD}$, Associate Professor, Department of Surgery and Anatomy, Ribeirão Preto Medical School, University of São Paulo. Critical revising and final approval of the version to be published.

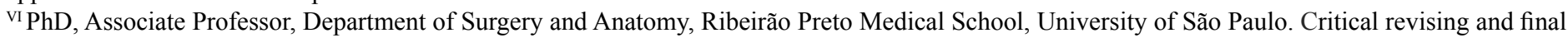
approval of the version to be published.

\begin{abstract}
PURPOSE: In this paper we report clinical variables on colon cancer series. Oncological outcomes were compared to low-income and high-income countries.

METHODS: We analysed a prospective database of 51 colon cancer patients submitted to primary tumor resection between 2010 and 2011, showing clinical variables and oncologic outcomes.

RESULTS: R0 resection obtained in $80.4 \%, 21.6 \%$ of patients was TNM stage IV, and only $13.7 \%$ showed TNM stage I. Diseasefree survival was 32 months, overall survival was 46 months, and the tumoral recurrence rate was $9.8 \%$. Univariate analysis showed association of serum CEA levels $\geq 5 \mathrm{ng} / \mathrm{dl}(\mathrm{p}=0.004)$, presence of metastasis at diagnosis $(\mathrm{p}=0.012)$, compromised surgical margins $(\mathrm{p}<0.001)$ and poorer tumor differentiation $(\mathrm{p}=0.041)$ to death. Multivariate analysis identified compromised surgical margins as an independent risk factor for death due to colon cancer $(\mathrm{P}=0.003$; odds ratio $=0.36$; $95 \%$ confidence interval $=0.004-0.33$ ). Nowadays, $62.7 \%$ of patients are alive.
\end{abstract}

CONCLUSION: Recurrence rate, disease-free survival and overall survival was similar to those observed in more developed countries. Serum CEA levels $\geq 5 \mathrm{ng} / \mathrm{dl}$, the presence of metastasis at diagnosis, compromised surgical margins and poorer tumor differentiation were associated with death. A compromised surgical margin was the only independent risk factor for death.

Key words: Colonic Neoplasms. Colon. Drug Therapy. Disease-Free Survival. Survival. 


\section{Introduction}

Colorectal cancer (CRC) is a significant health problem, and 1.4 million new cases were estimated worldwide, in $2012^{1}$. In the last decade, a progressive reduction in the annual incidence rate of the disease has been observed in the USA. However, CRC remains responsible for 50,000 annual deaths ${ }^{2}$. An increased incidence has been observed in patients under 50 years of age and in low-income countries ${ }^{3}$. In Brazil, almost 32,600 new cases were expected in 2014, and the disease represents the third leading cancer-related cause of death ${ }^{4}$.

CRC treatment has improved in the last decades, and overall survival has increased mainly due to the favorable effect of more efficient adjuvant chemotherapy regimens ${ }^{5}$. Despite the constant advances, the prognosis of CRC remains poor. Only $15 \%$ of patients with distant metastasis at diagnosis are expected to be alive after five years ${ }^{6}$. Five-year overall survival is less than $10 \%$ in Sub-Saharan Africa, 28\% in India and 49\% in Asia. On the other hand, high-income countries may reach a $65 \%$ overall survival after five years ${ }^{7}$.

Incidence and prognosis of distal and proximal colorectal cancers may not be the same. Differences could be explained by unequal molecular profiles characterized by allelic losses on chromosomes 17p, 18, and 5q, KRAS and p53 mutations observed more frequently in the left-side colon cancers ${ }^{6-7}$. Epidermal growth factor receptor (EGFR) is also overexpressed in distal colorectal cancers. Right-sided colon cancers are associated with v-RAF murine sarcoma viral oncogene homolog B (BRAF) mutations ${ }^{8}$.

The purpose of the present study is to describe the clinical outcomes in a group of CRC patients operated in a teaching hospital and to compare our results with recent data from other studies.

\section{Methods}

We conducted an analysis of a prospective database of colon cancer patients after approval from the Institutional Review Board. All subjects underwent surgery at Clinics Hospital, Ribeirão Preto Medical School (São Paulo, Brazil), between 2010 and 2011. Patients with recurrent tumors, previous history of other malignancies, a presence of synchronous CRC, rectal cancer and with an inherited predisposition of $\mathrm{CRC}$ were excluded from the study.
The collected variables were sex, age, race, American Society of Anesthesiology (ASA) classification, tumor topography, presence of lymphovascular invasion, histological differentiation grade, mucinous histologic subtype, number of retrieved lymph nodes, surgical margins, TNM staging (UICC, $7^{\text {th }}$ edition), serum carcinoembryonic antigen (CEA) levels at diagnosis, recurrence and overall survival.

Continuous variables were expressed as mean \pm standard deviation (SD). Independent categorical variables were compared with $\chi 2$ tests. Univariate analysis was conducted to test the individual association of independent variables with tumor recurrence and overall survival. All variables associated with recurrence and mortality were included in a final multivariate model. Survival curves were plotted using the Kaplan-Meier method. For all analyzes, a significance level of $5 \%$ was established.

\section{Results}

The study includes 51 patients. Mean age was 66 years (range, 34-88 years). Tables 1 and 2 summarize the clinical characteristics, histological features, and oncological outcomes of subjects.

TABLE 1 - Main characteristics of patients with colon cancer.

\begin{tabular}{cc}
\hline Characteristics & $\begin{array}{c}\text { Frequency } \\
\mathrm{N} /(\%)\end{array}$ \\
\hline Gender & $30(58.8 \%)$ \\
Male & $21(41.2 \%)$ \\
Female & \\
Ethnicity & $46(90.2 \%)$ \\
White & $4(7.8 \%)$ \\
African-American & $1(2 \%)$ \\
Asian & \\
ASA* & $8(15.7 \%)$ \\
I & $36(70.6 \%)$ \\
II & $7(13.7 \%)$ \\
III & \\
CEA (ng/mL) & $24(47 \%)$ \\
$>5.0$ & $27(53 \%)$ \\
$\leq 5.0$ & \\
Tumor location & $15(29.5 \%)$ \\
Right colon & $7(13.7 \%)$ \\
Transverse colon & $7(13.7 \%)$ \\
Left colon & $22(43.1 \%)$ \\
Sigmoid colon &
\end{tabular}

* American Society of Anesthesiologists Physical Status Classification System 
TABLE 2 - Main histological features and oncological outcomes of subjects with colon cancer.

\begin{tabular}{|c|c|}
\hline Characteristics & Frequency \\
\hline \multicolumn{2}{|l|}{ TNM staging } \\
\hline Stage I & $7(13.7 \%)$ \\
\hline Stage II & $17(33.3 \%)$ \\
\hline Stage III & $16(31.4 \%)$ \\
\hline Stage IV & $11(21.6 \%)$ \\
\hline \multicolumn{2}{|c|}{ Metastasis Site at diagnosis $(n=11)$} \\
\hline Liver isolated & $4(36.3 \%)$ \\
\hline Liver + lung & $2(18.2 \%)$ \\
\hline Liver + peritoneum & $2(18.2 \%$ \\
\hline Lung isolated & $1(9.1 \%)$ \\
\hline Peritoneum isolated & $2(18.2 \%)$ \\
\hline \multicolumn{2}{|l|}{ Lymphovascular invasion } \\
\hline Present & $19(37.3 \%)$ \\
\hline Absent & $29(56.9 \%)$ \\
\hline Not evaluated & $3(5.8 \%)$ \\
\hline \multicolumn{2}{|l|}{ Tumor differentiation } \\
\hline Well differentiated & $7(13.7 \%)$ \\
\hline Moderately differentiated & $36(70.6 \%)$ \\
\hline Poorly differentiated & $6(11.8 \%)$ \\
\hline Not evaluated & $2(3.9 \%)$ \\
\hline \multicolumn{2}{|l|}{ Mucinous histologic subtype } \\
\hline Present & $13(25,5 \%)$ \\
\hline Absent & $36(70,6 \%)$ \\
\hline Not evaluated & $2(3,9 \%)$ \\
\hline $\begin{array}{r}\text { Number of retrieved } \\
\text { Mean (rang } \\
12,2(1-46\end{array}$ & \\
\hline \multicolumn{2}{|l|}{ Surgical margins } \\
\hline R0 & $41(80,4 \%)$ \\
\hline $\mathrm{R} 1$ & $1(2 \%)$ \\
\hline $\mathrm{R} 2$ & $9(17,6 \%)$ \\
\hline \multicolumn{2}{|l|}{ Tumor recurrence } \\
\hline Present & $5(9,8 \%)$ \\
\hline Absent & $46(90,2 \%)$ \\
\hline \multicolumn{2}{|l|}{ Recurrence site } \\
\hline Liver & $1(20 \%)$ \\
\hline Lung & $1(20 \%)$ \\
\hline Peritoneal & $3(60 \%)$ \\
\hline
\end{tabular}

The median follow-up was 46 months. Disease-free survival was 32 months (range, 0-60 months). Overall survival was 46 months (range, 1-62 months). Total mortality rate was
$37.3 \%(n=19)$. Final mortality rate according to disease staging was $41.2 \%(n=7)$ in stage II, $25 \%$ in stage III and $72.7 \%$ in stage IV subjects. Figure 1 evidences a Kaplan-Meier survival curve according to pathological staging.

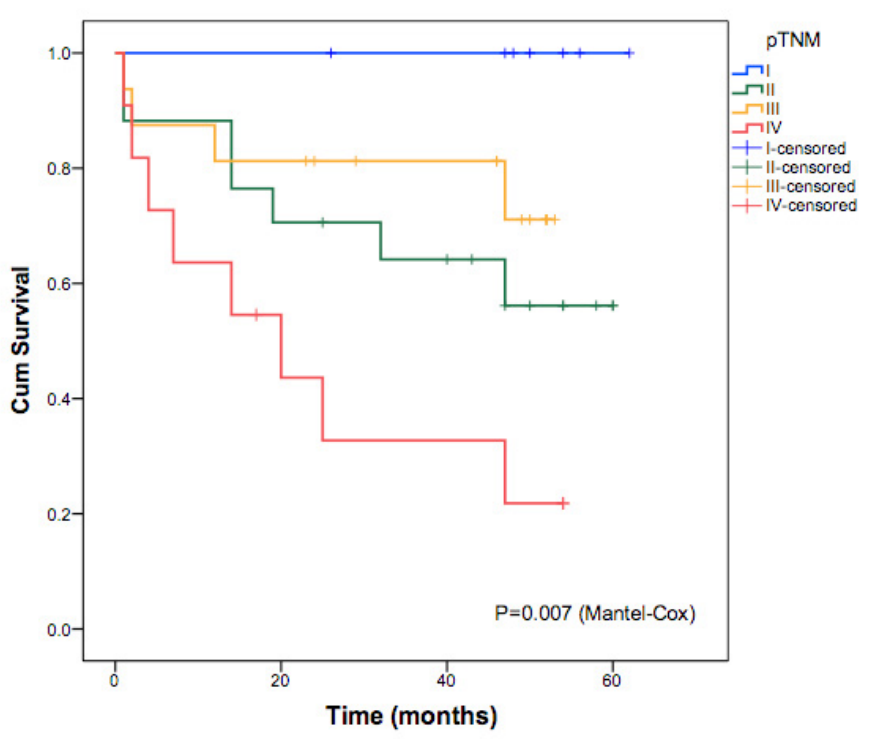

FIGURE 1 - Kaplan-Meier 5-year survival curve according to pathological staging.

A univariate analysis was performed, and no association was found between recurrence and age, serum CEA, lymph node involvement, a presence of metastasis at diagnosis, surgical margins, lymphovascular invasion, the presence of mucinous subtype and tumor differentiation. Death was associated with serum CEA levels $\geq 5 \mathrm{ng} / \mathrm{dl}$, a presence of metastasis at diagnosis, compromised surgical margins and poorer tumor differentiation. After, the final multivariate analysis was built and compromised surgical margins was identified as an independent risk factor for death due to colon cancer $(P=0.003$; odds ratio $=0.36$; $95 \%$ confidence interval $=0.004-0.33)$. Table 3 summarizes the univariate analysis of variable associated with recurrence and death. 
TABLE 3 - Univariate analysis - independent variables associated with disease recurrence or death

\begin{tabular}{|c|c|c|c|c|}
\hline $\begin{array}{c}\text { Independent } \\
\text { variables }\end{array}$ & $\begin{array}{c}\text { Recurrence } \\
\mathrm{N} /(\%)\end{array}$ & $P^{*}$ & $\begin{array}{c}\text { Death } \\
\mathrm{N} /(\%)\end{array}$ & $P^{*}$ \\
\hline $\begin{array}{c}\text { Age (years) } \\
\geq 70 \\
<70\end{array}$ & $\begin{array}{l}2(5.6 \%) \\
3(20 \%)\end{array}$ & 0.144 & $\begin{array}{c}12(33.3 \%) \\
7(46.7 \%)\end{array}$ & 0.526 \\
\hline $\begin{array}{c}\text { Serum CEA } \\
\begin{array}{c}(\mathbf{n g} / \mathbf{d l}) \\
>5 \\
\leq 5\end{array}\end{array}$ & $\begin{array}{c}3(12.5 \%) \\
2(7.4 \%)\end{array}$ & 0.656 & $\begin{array}{c}14(58.3 \%) \\
5(18.5 \%)\end{array}$ & 0.004 \\
\hline $\begin{array}{c}\text { Lymph node } \\
\text { involvement } \\
\text { Absent } \\
\text { Present }\end{array}$ & $\begin{array}{c}3(12.5 \%) \\
2(7.7 \%)\end{array}$ & 0.661 & $\begin{array}{c}8(33.3 \%) \\
11(42.3 \%)\end{array}$ & 0.570 \\
\hline $\begin{array}{c}\text { Metastasis at } \\
\text { diagnosis } \\
\text { Absent } \\
\text { Present }\end{array}$ & $\begin{array}{c}5(12.5 \%) \\
0(0 \%)\end{array}$ & 0.572 & $\begin{array}{c}11(27.5 \%) \\
8(72.7 \%)\end{array}$ & 0.012 \\
\hline $\begin{array}{c}\text { Surgical } \\
\text { margins } \\
\text { Negative } \\
\text { Positive }\end{array}$ & $\begin{array}{c}4(9.8 \%) \\
1(10 \%)\end{array}$ & 1.000 & $\begin{array}{c}10(24.4 \%) \\
9(90 \%)\end{array}$ & $<0.001$ \\
\hline $\begin{array}{c}\text { Lymphovascular } \\
\text { invasion } \\
\text { Absent } \\
\text { Present }\end{array}$ & $\begin{array}{c}3(10.3 \%) \\
1(5.3 \%)\end{array}$ & 1.000 & $\begin{array}{c}7(24.1 \%) \\
10(52.6 \%)\end{array}$ & 0.065 \\
\hline $\begin{array}{c}\text { Mucinous } \\
\text { differentiation } \\
\text { Absent } \\
\text { Present }\end{array}$ & $\begin{array}{c}3(8.3 \%) \\
2(15.4 \%)\end{array}$ & 0.598 & $\begin{array}{c}11(30.6 \%) \\
7(53.8 \%)\end{array}$ & 0.184 \\
\hline $\begin{array}{c}\text { Tumor } \\
\text { differentiation } \\
\text { Well } \\
\text { Poor/moderate }\end{array}$ & $\begin{array}{c}3(7.1 \%) \\
1(14.3 \%)\end{array}$ & 0.472 & $\begin{array}{c}12(28.6 \%) \\
5(71.4 \%)\end{array}$ & 0.041 \\
\hline
\end{tabular}

* Fisher's Exact Test

\section{Discussion}

The incidence of CRC has decreased in developed countries. The same trend was not observed in low-income regions, which have been responsible for $50 \%$ of all new diagnoses of the disease, in the last 25 years. This observation may be associated with a "Western lifestyle" and risk factors such as smoking and excessive alcohol intake".

The mean age at diagnosis was similar to that found in developed countries ${ }^{10}$. More than half of all subjects were diagnosed with a locoregional and metastatic disease. A possible explanation for this observation could be limited public health budget and low accessibility to screening programs ${ }^{3,11}$.
Although not evidenced in the present study, a lymphovascular invasion is usually associated with higher risk of lymph node spread, distant metastasis and poorer prognosis in other series ${ }^{12}$. The rate of poorly differentiated tumors may reach $25 \%$ in recent studies, and histological differentiation is considered an independent risk factor of poor prognosis ${ }^{13}$. We observed a higher risk of mortality in the poorly differentiated group; however, our results suggest that this may be due to the effects of confounding factors. In many series, the mucinous histologic subtype is associated with higher risk of incomplete resection and poor prognosis ${ }^{14}$. The high incidence observed in this series could be explained by geographical variations and the absence of rectal tumors that exhibit less mucinous differentiation ${ }^{15}$. We found no association of mucinous differentiation with recurrence and mortality, although the small number of patients may have interfered with our results.

Lymph node involvement is one of the most significant prognostic factors in CRC. Intergroup Trial INT-0089 evaluated 3,411 CRC patients and noted that the number of retrieved lymph nodes was related to overall survival, even in N0 patients ${ }^{16}$. A systematic review conducted by Chang et al. with 61,371 patients observed a positive association between overall survival ${ }^{17}$. The ideal number of retrieved lymph node should be at least 12 . However, recent studies have discussed the role of total numbers of lymph nodes retrieved, lymph node ratio, size and immune activation of lymph nodes ${ }^{18,19}$

In the present study, the high number of R1 and R2 resections is probably a consequence of the high rate of advanced disease and palliative procedures. Of note, all stage IV patients who were submitted to primary tumor excision without metastasis resection were considered as $\mathrm{R} 2$. Compromised margins were an independent risk factor for mortality.

The surgeon should weigh several parameters before recommending a palliative procedure including patient preference, performance status, and symptoms. Moreover, some features of the tumor are important in this situation, such as the extension of the primary mass, tumor burden and response to systemic chemotherapy ${ }^{20,21}$.

Despite all treatment advances, tumor recurrence remains a major problem in CRC. In other series, recurrence rates may range from $4-16 \%{ }^{22,23}$. Tumor perforation, advanced-stage disease, and poor differentiation appear to increase recurrence after curative treatment ${ }^{24}$. In the present study, no variable was associated with recurrence. However, this could be explained by the small sample size. 
In the present study, overall survival was similar to the rates observed in more developed countries, as noted in Table 4. Some factors were associated with death including serum CEA levels $\geq 5 \mathrm{ng} / \mathrm{dl}$, a presence of metastasis at diagnosis, compromised surgical margins, and poorer tumor differentiation. However, a compromised surgical margin was the only independent risk factor for death. In summary, this results encourage us to achieve an R0 resection as a major goal of colon cancer therapy.

TABLE 4 - Comparative evaluation of oncologic outcomes from low-income and high-income countries.

\begin{tabular}{|c|c|c|c|c|c|c|}
\hline Study & Continent & $\begin{array}{l}\text { TNM } \\
\text { Stage }\end{array}$ & $\begin{array}{l}\text { Mean age } \\
\text { (years) }\end{array}$ & Tumor Site & Follow-up & $\begin{array}{c}\text { 5-year Overall } \\
\text { survival }\end{array}$ \\
\hline Siegel, $2014^{3}$ & North America & I-IV & 71 & Colorectal & $2003-2009$ & $64,9 \%$ \\
\hline Sankaranarayanan, $2010^{25}$ & Asia & I-IV & 62 & Colorectal & $1990-2003$ & $28-60 \%$ \\
\hline \multirow[t]{5}{*}{ Allemani, $2015^{26}$} & Africa & NA & NA & Colon & $1995-2009$ & $0,1-57,2 \% \$$ \\
\hline & North America & NA & NA & Colon & $1995-2009$ & $56,8-64,7 \%$ \$ \\
\hline & Asia & NA & NA & Colon & $1995-2009$ & $28,1-68,4 \%{ }^{\mathrm{s}}$ \\
\hline & Europe & NA & NA & Colon & $1995-2009$ & $35,5-65,1 \% \$$ \\
\hline & $\begin{array}{c}\text { Oceania } \\
\text { NA } \\
\text { NA } \\
\text { Colon }\end{array}$ & & & & $1995-2009$ & $60,3-64,2 \%$ \\
\hline
\end{tabular}

NA: not available; \#: estimated; \$: 5-year net survival;

\section{Conclusions}

In the present study, recurrence rates and overall survival was similar to those observed in more developed countries. This could be explained by the fact that treatment and follow-up of patients were carried out in the wealthiest state in Brazil, with easier access to health resources.

Serum CEA levels $\geq 5 \mathrm{ng} / \mathrm{dl}$, a presence of metastasis at diagnosis, compromised surgical margins and poorer tumor differentiation were associated with death. A compromised surgical margin was the only independent risk factor for death.

\section{References}

1. Global battle against cancer won't be won with treatment alone - Effective prevention measures urgently needed to prevent cancer crisis. Cent Eur J Public Health. 2014 Mar;22(1):23, 28.PMID:24844101.

2. Siegel R, Ma J, Zou Z, Jemal A. Cancer statistics, 2014. CA Cancer J Clin. 2014;64(1):9-29.PMID:24399786.

3. Siegel R, Desantis C, Jemal A. Colorectal cancer statistics, 2014. CA Cancer J Clin. 2014;64(2):104-17. PMID:24639052.

4. Instituto Nacional de Câncer José Alencar Gomes da Silva (INCA). Estimativa 2014: incidência de câncer no Brasil. In Vigilância CdPe, editor. Rio de Janeiro: INCA; 2014:124.
5. Gustavsson B, Carlsson G, Machover D, Petrelli N, Roth A, Schmoll HJ, Tveit KM, Gibson F. A review of the evolution of systemic chemotherapy in the management of colorectal cancer. Clin Colorectal Cancer. 2015;14(1):1-10.PMID:25579803.

6. Delattre O, Olschwang S, Law DJ, Melot T, Remvikos Y, Salmon RJ, Sastre X, Validire P, Feinberg AP, Thomas G. Multiple genetic alterations in distal and proximal colorectal cancer. Lancet. 1989;2(8659):353-6. PMID:2569552.

7. Lee GH, Malietzis G, Askari A, Bernardo D, Al-Hassi HO, Clark SK. Is right-sided colon cancer different to left-sided colorectal cancer? - a systematic review. Eur J Surg Oncol. 2015;41(3):300-8. PMID:25468456.

8. Tamas K, Walenkamp AM, de Vries EG, van Vugt MA, Beets-Tan RG, van Etten B, de Groot DJ, Hospers GA. Rectal and colon cancer: Not just a different anatomic site. Cancer Treat Rev. 2015;41(8):6719. PMID:26145760.

9. Brenner H, Kloor M, Pox CP. Colorectal cancer. Lancet. 2014;383(9927):1490-502.PMID:24225001.

10. Siegel R, DeSantis C, Virgo K, Stein K, Mariotto A, Smith T, Cooper D, Gansler T, Lerro C, Fedewa S, Lin C,Leach C, Cannady RS, Cho H, Scoppa S, Hachey M, Kirch R, Jemal A, Ward E. Cancer treatment and survivorship statistics, 2012. CA Cancer J Clin. 2012;62(4):220-41.PMID:22700443.

11. Coleman MP. Cancer survival in the developing world. Lancet Oncol. 2010;11(2): 110-1. PMID:20005176.

12. Minsky BD, Mies C, Rich TA, Recht A. Lymphatic vessel invasion is an independent prognostic factor for survival in colorectal cancer. Int J Radiat Oncol Biol Phys. 1989;17(2):311-8.PMID:2546907.

13. Barresi V, Reggiani Bonetti L, Ieni A, Caruso RA, Tuccari G. Histological grading in colorectal cancer: new insights 
and perspectives. Histol Histopathol. 2015;30(9):1059-67. PMID:26004398.

14. Hugen N, Brown G, Glynne-Jones R, de Wilt JH, Nagtegaal ID. Advances in the care of patients with mucinous colorectal cancer. Nat Rev Clin Oncol. 2015. PMID:26323388.

15. Hugen $\mathrm{N}$, van Beek JJ, de Wilt JH, Nagtegaal ID. Insight into mucinous colorectal carcinoma: clues from etiology. Ann Surg Oncol. 2014;21(9):2963-70. PMID:24728741.

16. Le Voyer TE, Sigurdson ER, Hanlon AL, Mayer RJ, Macdonald JS, Catalano PJ, Haller DG. Colon cancer survival is associated with increasing number of lymph nodes analyzed: a secondary survey of intergroup trial INT-0089. J Clin Oncol. 2003;21(15):2912-9. PMID:12885809.

17. Otchy D, Hyman NH, Simmang C, Anthony T, Buie WD, Cataldo P, Church J, Cohen J, Dentsman F, Ellis CN,Kilkenny JW 3rd, Ko C, Moore R, Orsay C, Place R, Rafferty J, Rakinic J, Savoca P, Tjandra J, Whiteford M;Standards Practice Task Force; American Society of Colon and Rectal Surgeons. Practice parameters for colon cancer. Dis Colon Rectum. 2004;47(8):1269-84.PMID:15484340.

18. Markl B, Schaller T, Kokot Y, Endhardt K, Kretsinger H, Hirschbuhl K,Aumann G, Schenkirsch G. Lymph node size as a simple prognostic factor in node negative colon cancer and an alternative thesis to stage migration. Am J Surg. 2015. PMID:26307422.

19. Parnaby CN, Scott NW, Ramsay G, MacKay C, Samuel L, Murray GI, Loudon MA. Prognostic value of lymph node ratio and extramural vascular invasion on survival for patients undergoing curative colon cancer resection. Br J Cancer. 2015;113(2):212-9. PMID:26079302.

20. Tan WJ, Chew MH, Tan Bee Huat I, Law J, Zhao R, Acharyya S, Mao YL, Fernandez LG, Loi CT, Tang CL. Palliative surgical intervention in metastatic colorectal carcinoma - a prospective analysis of quality of life. Colorectal Dis. 2015. PMID:26437936.

21. Tarantino I, Warschkow R, Guller U. Palliative Primary Tumor Resection in Patients With Metastatic Colorectal Cancer: For Whom and When?. Ann Surg. 2015.PMID:26079906.

22. Read TE, Mutch MG, Chang BW, McNevin MS, Fleshman JW, Birnbaum EH, Fry RD, Caushaj PF, Kodner IJ. Locoregional recurrence and survival after curative resection of adenocarcinoma of the colon. J Am Coll Surg. 2002;195(1):33-40. PMID:12113543.

23. Yun HR, Lee LJ, Park JH, Cho YK, Cho YB, Lee WY, Kim HC, Chun HK, Yun SH. Local recurrence after curative resection in patients with colon and rectal cancers. Int $\mathrm{J}$ Colorectal Dis. 2008;23(11):1081-7. PMID:18688621.
24. Harris GJ, Church JM, Senagore AJ, Lavery IC, Hull TL, Strong SA, Fazio VW. Factors affecting local recurrence of colonic adenocarcinoma. Dis Colon Rectum. 2002;45(8):1029-34. PMID:12195186.

25. Sankaranarayanan R, Swaminathan R, Brenner H, Chen K, Chia KS, Chen JG, Law SC, Ahn YO, Xiang YB, Yeole BB, Shin HR, Shanta V, Woo ZH, Martin N, Sumitsawan Y, Sriplung H, Barboza AO, Eser S, Nene BM,Suwanrungruang K, Jayalekshmi P, Dikshit R, Wabinga H, Esteban DB, Laudico A, Bhurgri Y, Bah E, Al-Hamdan N.Cancer survival in Africa, Asia, and Central America: a population-based study. Lancet Oncol. 2010;11(2):165-73. PMID:20005175.

26. Allemani C, Weir HK, Carreira H, Harewood R, Spika D, Wang XS, Bannon F, Ahn JV, Johnson CJ, Bonaventure A, Marcos-Gragera R, Stiller C, Azevedo e Silva G, Chen WQ, Ogunbiyi OJ, Rachet B, Soeberg MJ, You H,Matsuda T, Bielska-Lasota M, Storm H, Tucker TC, Coleman MP; CONCORD Working Group. Global surveillance of cancer survival 1995-2009: analysis of individual data for 25,676,887 patients from 279 population-based registries in 67 countries (CONCORD-2). Lancet. 2015;385(9972):977-1010. PMID:25467588.

\section{Correspondence:}

Mário Vinícius Angelete Alvarez Bernardes

Av. Bandeirantes, 3900 - Campus Universitário - Monte Alegre - $9^{\circ}$ andar 14048-900 - Ribeirão Preto, SP, Brasil

Tel.: (55 16) 3602-2509

mariobernardes@usp.br

Conflict of interest: none

Financial source: none

${ }^{1}$ Research performed at Department of Surgery and Anatomy, Ribeirão Preto Medical School, University of São Paulo. 